\title{
DOI 10.26886/2520-7474.5(31)2018.4
}

UDC: $152+155.5+153.1+152.26+155.4$

CREATIVITY AS THE PERFORMANCE OF VISUAL INTELLIGENCE AND ITS DEVELOPMENT

\section{S. M. Symonenko, Doctor of Psychology, Professor}

\section{V. Rozina, PhD in Psychological Sciences, Associate Professor}

State Institution «South Ukrainian national pedagogical university after K. D. Ushynsky», Ukraine, Odessa

The actual problem of studying creativity as properties of visual thinking and development of its procedural and substantive characteristics is considered. By visual creativity, we mean the empirical characteristic of visual thinking, which is related to its creative function and is aimed at creating new visual images, symbols, models through visualization operations based on verbal and visual stimuli. The processual components of visual and thinking creativity are the activity of hypothesizing, productivity, visual originality.

The relevance of the study is related to the need to study visual thinking as one of the mechanisms of creativity in various fields of human activity, which is not sufficiently studied and requires a more in-depth study, in particular, one of its main properties - visual creativity and its development. The purpose of our research is to study the visual creativity and development of its procedural and substantive characteristics. By visual creativity, we mean the empirical characteristic of visual thinking, which is related to its creative function and is aimed at creating new visual images, symbols, models through visualization operations based on verbal and visual stimuli. The general methodology of empirical research includes the following methods, observation, analysis of product activities, the method of $P$. Torrance's test; U. Ave-Lallemant's "Stars and Waves" Graphic Test and 
the methods of mathematical statistics, the Student's t-test, the correlation analysis, and others. The research sample was 125 adolescents aged 10 to 14 years (25 students in each age group).

The analysis of the results of the empirical research has shown that the age of 10 and 13 is favorable for the development of both procedural and content characteristics of visual creativity.

The obtained results allow us to make a generalization that the development of content components of visual creativity occurs in parallel with the development of its procedural characteristics. Both content and procedural components have in their development both favorable periods and periods of decline, which coincide in time, but there is a clear tendency towards their development in adolescence and the formation of visualthinking creative strategies.

Key words: visual thinking, visual creativity, procedural characteristics, hypothesizing activity, performance, visual originality, content characteristics

доктор психологічних наук, профресор, Симоненко С. М., кандидат психологічних наук, доцент Розіна І. В. Креативність як властивість візуального мислення та їі розвиток/ Державний заклад «Південноукраїнський національний педагогічний університет імені К. Д. Уиинського», Україна, Одеса

Розглянута актуальна проблема вивчення креативності як властивості візуального мислення та розвитку їі процесуальних та змістових характеристик. Під візуальною креативністю ми розуміємо емпіричну характеристику візуального мислення, що пов'язана з його креативною функцією і спрямована на створення нових наочних образів, символів, моделей за допомогою операцій візуалізації на основі вербальних та візуальних стимулів. Процесуальними компонентами візуально-мисленнєвої креативності 
$\epsilon$ активність висування гіпотез, продуктивність, візуальна оригінальність.

Актуальність дослідження пов'язана з необхідністю вивчення візуального мислення як одного з механізмів творчості в різних галузях людської діяльності, що є недостатньо вивченим і потребує більш глибокого дослідження, зокрема, однієї з його основних властивостей - візуальної креативності та їі розвитку. Метою нашого дослідження $\epsilon$ вивчення візуальної креативності та розвитку ї процесуальних та змістових характеристик. Під візуальною креативністю ми розуміємо емпіричну характеристику візуального мислення, що пов'язана з креативною фрункцією візуального мислення і спрямована на створення нових наочних образів, символів, моделей за допомогою операцій візуалізації на основі вербальних та візуальних стимулів. В загальну методику емпіричного дослідження увійшли такі методи, як спостереження, аналіз продуктів діяльності, методика П. Торренса, методика У. Аве-Лаллемант, Графрический тест «Звезды и волны». Та методи математичної статистики, Критерій Ст'юдента, кореляційний аналіз та інші. Дослідницьку вибірку склали 125 підлітків віком від 10 до 14 років (по 25 учнів в кожній віковій групі).

Аналіз результатів емпіричного дослідження показав, що сприятливим для розвитку як процесуальних, так і змістових характеристик візуальної креативності є вік 10 та 13 років.

Одержані результати дозволяють зробити узагальнення про те, що розвиток змістових компонентів візуальної креативності відбувається паралельно із розвитком ї процесуальних характеристик. Як змістові так і процесуальні компоненти мають у своєму розвитку як сприятливі періоди, так і періоди спаду, які співпадають у часі, але $є$ чітка тенденція до їх розвитку у 
підлітковому віці та становлення візуально-мисленнєвих творчих cmpameziŭ.

Ключові слова: візуальне мислення, візуальна креативність, процесуальні характеристики, активність висування гіпотез, продуктивність, візуальна оригінальність, змістові характеристики

Актуальність дослідження пов'язана 3 необхідністю вивчення візуального мислення як одного з механізмів творчості в різних галузях людської діяльності, що є недостатньо вивченим і потребує більш глибокого дослідження, зокрема, однієї з його основних властивостей візуальної креативності та ії розвитку. Метою нашого дослідження $€$ вивчення візуальної креативності та розвитку ії процесуальних та змістових характеристик. Під візуальною креативністю ми розуміємо емпіричну характеристику візуального мислення, що пов'язана 3 креативною функцією візуального мислення і спрямована на створення нових наочних образів, символів, моделей за допомогою операцій візуалізації на основі вербальних та візуальних стимулів.

Однією з основних функцій візуального мислення, на наш погляд, $є$ креативна фрункція. Оскільки візуально-мисленнєвий образ (образконцепт) $€$ не відображеним, а створеним образом [1], це припускає наявність елементів творчості в його творенні. Наочність означеного образу належить не до сфрери репродукції об'єкта в його чистому вигляді, а до сфрери реконструкції і конструювання (моделювання, перетворення, трансорормацій) об'єкта.

У працях як зарубіжних авторів (Арнхейм Р., Вертгеймер М., Зинченко В. П., Мунипов В. М., Гордон В. М., Вергілес Н. Ю.), так і вітчизняних дослідників (Моляко В. О., Симоненко С. М., Вовнянко Т. А., Грек О. М.) відзначається зв'язок візуального мислення з процесами творчості в різних галузях людської діяльності. Так, зокрема, Арнхейм 
Р., розглядаючи становлення різних художніх напрямків у візуальному живописі, стверджує, що “...образотворче мистецтво - це квінтесенція візуального мислення" [2]. Якщо розглядати приклади створення наукових концепцій, то зміст їх стає видимим як для широкої аудиторії, так і для самого творця через створення концептів чи моделей, що найповніше розкривають сутність саме завдяки здатності образівконцептів “значення робити видимим"[1].

Завдяки креативності візуально-мисленнєвих образів стає можливим одержання інформації про структурно-просторові і часові характеристики можливих світів шляхом наочно-образного перетворення схематичних зображень предметів і способів дії з ними, шляхом створення за допомогою візуалізації таких продуктів візуального мислення, як конструкцій, схем, макетів, картин, скульптур, що не існують у природі і соціумі, але завдяки візуалізації можуть бути матеріалізовані тобто опредмечені в реальному просторі і часі у “новий штучний об'єкт іншої природи" , або ж є ідеальним планом, проміжним етапом в одному з проектів реалізації задуму [2].

Необхідно відзначити, що саме поняття візуалізації (у нашому розумінні) припускає певну креативність суб'єкта діяльності. Ця індивідуальна інтерпретація тих чи інших явищ, їхньої внутрішньої суті В наочних образах $€$ творчим процесом, процесом створення індивідуальної картини світу в наочних образах, у проектуванні, ідеї задумів, реалізації.

Виходячи з фундаментального принципу активності психічного відображення (Виготський Л. С., Леонтьєв О. М., Смирнов С. Д., Асмолов О. Г. та інші), будь-який психічний образ $є$ продуктом активності суб'єкта, що творить, тобто, навіть у відношенні перцептивного образу акцент із проблеми стимулу переноситься «всередину» суб'єкта. Леонтьєв О. М. визначив активність суб'єкта як 
внутрішню передумову саморуху діяльності та ії самовираження. У структурі психічного образу, згідно з Леонтьєвим О. М., поряд із предметним значенням наявний особистісний смисл, який $є$ свого роду трансформатором перекладу предметного значення. Завдяки особистісному смислу відбувається розпредмечення зовнішнього світу, що Зінченко В. П. образно називає “світ-текст" [1]. Людина витягує зміст із світу-тексту, перекладає його на свою мову предметних, вербальних, операціональних чи візуальних значень. Цю процедуру він називає означуванням смислу. Означування смислу, побудова знаку і "розміщення" його між собою і світом - це і є Культура, - вважає автор. Підвищуючи нашу загальну культуру, ми підвищуємо нашу здатність “бачення сутності речей”, здатність до “єдності (бачення) поглядів" як "взаєморозуміння" [1].

Креативна функція візуально-мисленнєвого образу визначається уже тим, що образ світу суб'єкта “при всій його неповноті і можливій неадекватності оригіналу надлишковий у тому розумінні, що містить у собі те, що не трапилось і містить навіть те, чого не може бути ніколи" (за Зінченко В. П.). Виходячи з цього, можна припустити, що образконцепт як творіння також має надлишкове число ступенів свободи стосовно образів чуттєвого відображення. Образ світу, створюваний людиною, $є$ не тільки повнішим, глибшим, ширшим, аніж це потрібно для вирішення повсякденних життєвих задач, він $є$ принципово іншим, аніж відображений у ньому світ. Завдяки відображеній в образі дії, образ стає знаком, чи, (за Зінченком В. П.), “практичним концептом”, “ручним поняттям", що породжує “невербальне внутрішнє слово” [1, с.136]. У зв'язку з цим, виникає питання про присвоєння думки, змісту через образ. Бахтін М. М. розглядає наступну послідовність у присвоєнні слова, знань, символів, образів тощо: чуже, чуже-своє, своє-чуже, своє. Через цей механізм відбувається присвоєння культури 
загалом, “яка стає своєю культурою”. При цьому, однією 3 характеристик індивідуальності, $є$ “своє слово в культурі” [1, с.141]. На наш погляд, цю думку Бахтіна М. М. можна трактувати досить широко, зважаючи на різні види діяльності людини, це відноситься не тільки до слова, але і до інших продуктів діяльності людини, і зокрема, до “образів створених", тобто візуальних образів.

Візуальний образ може бути афективно забарвленим, суб'єкт діяльності наповнює його суб'єктивним смислом (індивідуальним баченням), що знаходить своє вираження як у суб'єктивній семантиці образу (смислу), так і в особливостях його створення (операціональний компонент). Таким чином, афективне ставлення до створюваного візуального образу тісно пов'язане з особистісним смислом останнього й обумовлює його.

Смисл, на відміну від значення, схоплюється нами комплексно, симультанно. Тому нерідко сприймання і розуміння проблемності якоїсь ситуації виникає миттєво, навіть без попередньої побудови ії образно-концептуальної моделі. Отже, виходячи з цього, ми можемо розглядати симультанність як важливу властивість візуального образу. Означена властивість візуального образу дає нам перспективу одержання більшої кількості інформації, аніж при дискретному ії отриманні. Інформація може передаватися через візуальні образи, візуальні знаки, візуальні символи, просторово-часові моделі і схеми. У процесі візуальної комунікації ми можемо пізнавати мову глибинних структур (пластів) образу світу, починаючи від структур свідомості до структур несвідомого [4].

Креативність візуально-мисленнєвого образу забезпечується в певній мірі його амодальністю. Шерег дослідників Артем'єва О. Ю., Петренко В. П., Шмельов О. Г. та інші) основу амодальності візуального образу вбачають у глибинних мовних, семантичних 
структурах. Таким чином, постає питання про структурну подібність моторної, візуальної і вербальної мов опису світу, але, на сьогодні немає прямих доказів такої структурної подібності. Зінченко В.П.[1] вважає, що в основі амодальності візуального образу лежить мова моторних програм, що виконує також фрункцію транслятора при перекладі інформації з вербальної мови на мову візуальних образів чи інші мови, які існують у просторі мов, повний набір яких, на думку вченого, ще невідомий. Більше того, під час цього перекладу знання не тільки не губляться, але й відбувається їх приріст, вони набувають нових фрорм, вважає автор. Можна припустити, вважає вчений, що порівнюються між собою не різномодальні образи, а моторні програми. Зорова система дає імпульс до формування образу-плану потрібної дії, а кінестетична система фрормує моторну програму, яка визначається ситуацією дії. Їх зіставлення виявляється можливим, оскільки вони виражені однією мовою [3].

Отже, ми бачимо, що подібність візуальних і вербальних мов констатується на рівні моторних програм, що цілком узгоджується 3 діяльнісним підходом до розуміння процесів психічного відображення.

Дослідження Беспалова Б. І. також підтверджують тісний зв'язок моторики з зоровим образом [3]. На думку вченого, візуальний образ не статичний. Він дихає, змінюється, збіднюється, збагачується, перебудовується у власних інтересах і в інтересах регульованого ним руху, дії. Стосовно його динаміки введені терміни “оперування", “маніпулювання образом”. Встановлено подібність структур мануальної і візуальної моторики (рухів ока) у розв язанні задач наочно-дієвого і візуального мислення.

Виходячи з цього, можна зробити висновок про те, що властивість амодальності дає підставу вважати візуальний образ, порівняно 3 перцептивним образом, більш складною фрормою психічного 
відображення.

Креативність візуального мислення ґрунтується також на тому, що той самий об'єкт, та сама предметна ситуація, реальність, актуальна чи шукана цілісність, може бути прототипом величезної кількості різних моделей чи моделювальних уявлень. Таким чином, творча (креативна) функція візуального мислення реалізується в створенні моделей (наприклад, складних проблемних ситуацій, завдяки яким (моделям) їх розв'язання стає видимим, образів-концептів, візуальних знаків, символів, а також різних артономічних форм.

Важливу роль візуальне моделювання виконує у теоретичному мисленні. Моделі чи моделювальні уявлення як головні засоби теоретичного мислення., можуть бути виражені найрізноманітнішими мовами. Виділяють наочно-образні, вербально-описові, знакові, символічні, концептуальні, а також можуть мати і фрізичну подобу оригіналу і відображати різні види предметної діяльності. Їх умовно називають первинними моделями [3].

До вторинних моделей відносяться так звані "моделі моделей." Зокрема, мова може . розглядатися як модель дійсності, але разом 3 тим існують і моделі мови, тобто вторинні моделюючі уявлення (образконцепт). Таким чином, під моделлю розуміють фрункціональне гомоморфне перенесення (відображення) частини зовнішнього світу на систему понять (зображень, візуалізованих картин, символів, знаків). Це відображення не є ізоморфним, тобто взаємно однозначним, однак воно зберігає істотні зв'язки між елементами зовнішнього світу чи первинної моделі. Остання властивість дозволяє моделі бути не тільки описовою, але і виконувати функцію передбачення [4].

На наш погляд, необхідність вивчення візуальних мовних систем $€$ очевидною, оскільки дає можливість більш глибинного розкриття людської індивідуальності, багатогранності її творчого потенціалу. 
Візуально-мисленнєвому образу властива антиципація в наочній формі, що $є$ підґрунтям випереджального відображення дійсності, продукування раніше невідомих сутностей. Ця здатність наочності візуально-мисленнєвого образу $є$ сполучною ланкою між відомим і невідомим. Завдяки візуальним образам ми можемо намалювати картину кінцевого результату своїх досліджень, тобто здійснити прогнозування [4]. Оскільки специфікою візуального образу $є$ домінування раціонального над чуттєвим, то у візуальному образі простежується логічний зв'язок між минулим (несе в собі момент суб'єктивності) і майбутнім (від міри суб'єктивності залежить міра його реальності).

Наявність оперативних компонентів у наочних образах дозволяє образам трансформуватися в перцептивно-моторні схеми і виконувати функцію регуляції поведінки з урахуванням зовнішніх обставин, відповідних їм мотиваційних і цільових аспектів діяльності (наочного образу-мети) [3].

Специфіка візуального мислення полягає в тому, що візуальний образ у своїй наочності здатний ефективно відображати практично будь-які категоріальні відносини реальності: це просторово-часові, атрибутивні, каузальні, телеологічні, екзистенціальні й інші (за Ітельсоном Б. І.). Він робить їх “видимими”, втілюючи у просторовочасовій структурі, трансформуючи у динамічні моделі, які відповідають певному рівню візуальної креативності.

Наочні образи мають величезну інформаційну ємність. У них знаходить місце інформація про просторово-часові, динамічні, колірні і фігуративні характеристики предметів. Вони $€$ багатовимірними, багатокатегоріальними, а також амодальними. В образах відбиваються не тільки фрундаментальні перцептивні категорії, але і відношення між ними, як у рамках однієї категорії, так і інтермодальні відношення. 
Порівняно зі слуховими і руховими образами вони характеризуються суб'єктивною симультанністю, що дозволяє миттєво "схоплювати" відношення між елементами реальної або уявної ситуації. До таких образів можна віднести образи планетарної моделі атома, подвійної спіралі генетичного коду, генома культурного і духовного розвитку семіосфрери [1; 4], тощо.

Виходячи 3 основних положень стратегіально-семантичного підходу до вивчення візуального мислення [4; 5], ми розглядаємо візуальні образи як культурно опосередковані, що мають знакову природу і водночас вони завжди індивідуально опосередковані особистісними смислами. Провідними чинниками розвитку візуального мислення $€$ загальна “картина світу” як інтегруюча частина ментальності, властива певному суспільству, та індивідуальний “образ світу" суб`єкта, який формується в процесі розпредмечування ним цієї “картини світу” та опредмечування навколишнього світу. Ці чинники визначають візуально-мисленнєві стратегіi, які $€$ індивідуальними механізмами створення образу-концепту, візуальної креативності.

Візуально-мисленнєва стратегія розглядається нами як система індивідуально та особистісно усталених тенденцій до використання способів і прийомів трансформації та суб'єктивно-семантичної інтерпретації образу-концепту, що може реалізовуватися як на усвідомлюваному, так і на неусвідомлюваному рівні, яка $\epsilon$ індивідуально-особистісно та діяльнісно обумовленою, функціонально усталеною і реалізується в процесі творення візуально мисленнєвого образу при розв ‘занні тих чи інших творчих задач. Все це робить візуально-мисленнєві образи неповторними та креативними за своєю природою.

Дослідження візуально-мисленнєвої креативності дає нам можливість поглибити наше уявлення про візуальне мислення як 
продуктивну діяльність та ії̈ механізми, що є підґрунтям індивідуальної неповторності та креативності при розв язанні творчих задач.

Метою нашого емпіричного дослідження $€$ виявлення особливостей розвитку процесуальних та змістових характеристик візуальної креативності у підлітковому віці. Структурними компонентами візуально-мисленнєвої креативності $€$ активність висування гіпотез, продуктивність, візуальна оригінальність.

Чому саме було обрано підлітковий вік. Виходячи з досліджень Симоненко С. М. [6] саме підлітковий вік $€$ сенситивним для розвитку візуального мислення, його змістових та операційних компонентів та його креативної функції. При обранні методик для дослідження враховувались їх валідність і надійність, відповідність віку досліджуваних, діагностична спроможність в отриманні кількісних і якісних показників діагностованого явища.

Для вивчення процесуальних компонентів креативності було взято окремі показники (активність висування гіпотез, продуктивність, вербальна оригінальність, візуальна оригінальність) Тесту П.Торренса. Методика „Зірки та хвилі” У. Аве-Лаллемант [7] дозволяє розглянути змістові характеристики креативності.

Всього було обстежено 125 підлітків віком від 10 до 14 років, а в кожну вікову групу входила однакова кількість досліджуваних (25 осіб). Результати дослідження піддавалися кількісному та якісному аналізу.

Розглянемо показники активності висування візуальних гіпотез.

Таблиця 1

\section{Варіативність індивідуальних оцінок за показником} активності висування візуальних гіпотез

\begin{tabular}{|c|c|c|c|c|c|}
\hline & \multicolumn{5}{|c|}{ Групи досліджуваних } \\
\hline & 10 років & 11 років & 12 років & 13 років & 14 років \\
\hline Варіативність & $9-41$ & $10-40$ & $11-37$ & $8-39$ & $8-40$ \\
\hline
\end{tabular}




\begin{tabular}{|l|l|l|l|l|l}
\hline Різниця & 32 & 30 & 26 & 31 & 32 \\
\hline
\end{tabular}

Аналіз результатів первинних даних (табл.1.), показав, що варіативність індивідуальних оцінок за показником активності висування візуальних гіпотез у підлітків 10 років становить від 9 до 41 балів. Надалі спостерігається зменшення діапазону варіативності: в 11річних він становить від 10 до 40 балів, в 12-річних - від 11 до 37 балів. Натомість у старших підлітків 13 і 14 років ми спостерігаємо його збільшення: відповідно від 8 до 39 балів і від 8 до 40 балів.

Розглянемо динаміку показників активності висування візуальних гіпотез в різних вікових групах досліджуваних.

Таблиця 2

Показники активності висування візуальних гіпотез

\begin{tabular}{|c|c|c|c|c|c|}
\hline & \multicolumn{5}{|c|}{ Групи досліджуваних } \\
\hline Вік & 10 років & 11 років & 12 років & 13 років & 14 років \\
\hline Бали $\left(\mathrm{X}_{\text {сер. }}\right)$ & 25,20 & 22,68 & 22,32 & 24,90 & 20,42 \\
\hline
\end{tabular}

Наведені у таблиці 2 дані засвідчують достатній рівень розвитку активності висування візуальних гіпотез, показники якої змінюються відповідно віку досліджуваних. Однак, ці зміни мають неоднорідний і стрибкоподібний характер. Зниження продуктивності перцептивномисленнєвої сфрери відбувається в 11-12 років, де вона дорівнює відповідно 22,68 і 22,32 бали (у 10-річних підлітків продуктивність $€$ більшою і становить 25,20 бали). У 13-річних підлітків ми спостерігаємо зростання рівня активності висування візуальних гіпотез до 24,90 балів, після чого відбувається наступне його зниження до 20,42 балів у 14річних.

Таблиця 3

Значущість відмінностей показників активності висування візуальних гіпотез 


\begin{tabular}{|c|c|c|c|c|}
\hline & \multicolumn{4}{|c|}{ Групи досліджуваних, що порівнюються } \\
\hline Вік & $10 / 11 \mathrm{p}$. & $11 / 12 \mathrm{p}$. & $12 / 13 \mathrm{p}$. & $13 / 14 \mathrm{p.}$ \\
\hline $\mathrm{p}$ & 0,315 & 0,863 & 0,045 & 0,034 \\
\hline $\begin{array}{c}\text { Підвищення } \\
\text { оцінок }\end{array}$ & Незнач. & незнач. & знач. & Знач. \\
\hline
\end{tabular}

Результати перевірки отриманих даних показали (табл.3), статистично значущими виявилися відмінності між показниками підлітків 12 і 13 років ( $p=$ 0,045), а також підлітками 13 і 14 років $(p=0,34)$. Зміни в оцінках інших групах досліджуваних виявилися статистично незначущими.

Показник оригінальності назви виявляє креативний потенціал процесів вербально-образної трансформації, тобто визначає міру оригінальності вербалізації створеного образу.

Таблиця 4

Варіативність індивідуальних оцінок за показником вербальної оригінальності

\begin{tabular}{|c|c|c|c|c|c|}
\hline & \multicolumn{5}{|c|}{ Групи досліджуваних } \\
\hline & 10 років & 11 років & 12 років & 13 років & 14 років \\
\hline Варіативність & $0-30$ & $0-14$ & $0-19$ & $0-23$ & $0-21$ \\
\hline Різниця & 30 & 14 & 19 & 23 & 21 \\
\hline
\end{tabular}

Як бачимо 3 даних наведених у табл.4, варіативність індивідуальних оцінок в 10-річних підлітків коливається від 0 до 30 балів. В 11 - річних підлітків ми спостерігаємо його різке зменшення від 0 до 14 балів, різниця - 14 балів, після чого відбувається його поступове розширення від 0 до 19 балів в 12-річних, від 0 до 23 балів 13-річних. В 14-річних підлітків ми спостерігаємо зменшення діапазону варіативності від 0 до 21 балів, що попередньо може свідчити про зниження рівня вербальної оригінальності в даному віці.

Перевірка відмінностей кількісних показників оригінальності назви в різних вікових групах, результати якої наведено у табл.5, підтвердила 
статистично значущу достовірність розрізнення результатів підлітків $12 / 13$ років $(p=0,018)$ і підлітків $13-14$ років $(p=0,029)$. Це дозволяє говорити про якісне зростання креативного потенціалу процесів вербалізації старших підлітків порівняно з молодшими, оскільки у 10-11 років спостерігали деяке уповільнення у розвитку даної можливості.

Таблиця 4

\section{Значущість відмінностей за показником вербальної}

\section{оригінальності}

\begin{tabular}{|c|c|c|c|c|}
\hline & \multicolumn{4}{|c|}{ Групи досліджуваних, що порівнюються } \\
\hline Вік & $10 / 11 \mathrm{p}$. & $11 / 12 \mathrm{p}$. & $12 / 13 \mathrm{p}$. & $13 / 14 \mathrm{p}$. \\
\hline $\mathrm{p}$ & 0,787 & 0,739 & 0,018 & 0,029 \\
\hline $\begin{array}{c}\text { Підвищення } \\
\text { оцінок }\end{array}$ & незнач. & незнач. & знач. & Знач. \\
\hline
\end{tabular}

Показник візуальної оригінальності дозволяє визначити креативний потенціал процесів візуальної трансформації, здатність до створення нестандартного образу.

Таблиця 5

Варіативність індивідуальних оцінок за показником візуальної оригінальності

\begin{tabular}{|c|c|c|c|c|c|}
\hline & \multicolumn{5}{|c|}{ Групи досліджуваних } \\
\hline & 10 років & 11 років & 12 років & 13 років & 14 років \\
\hline Варіативність & $2-40$ & $0-27$ & $2-29$ & $0-56$ & $3-34$ \\
\hline Різниця & 38 & 27 & 29 & 56 & 31 \\
\hline
\end{tabular}

Як бачимо з даних, наведених у табл. 5, варіативність індивідуальних оцінок в підлітковому віці має неоднозначний характер. В 10-річних підлітків ії діапазон коливається від 2 до 40 балів, натомість в 11 років спостерігається різке зменшення діапазону від 0 до 27. Надалі відбувається поступове збільшення варіативності від 2 
до 29 балів - в 12-річних і від 0 до 56 балів -в 13-річних. Порівнюючи 3 13-річними підлітками, в 14-річних ми бачимо різке зниження варіативності від 3 до 34 балів. Це дозволяє нам дійти висновку, що в підлітковому віці розвиток візуальної креативності відбувається нерівномірно. Зниження креативного потенціалу процесів візуалізації виявляється в окремих досліджуваних в 11-12 і 14 років, в той час як у 10 і 13 років ми спостерігаємо позитивні зрушення у її розвитку.

Розглянемо дані, які виявляють динаміку розвитку візуальної оригінальності.

Таблиця 6

Показники візуальної оригінальності

\begin{tabular}{|c|c|c|c|c|c|}
\hline & \multicolumn{5}{|c|}{ Групи досліджуваних } \\
\hline Вік & 10 років & 11 років & 12 років & 13 років & 14 років \\
\hline & 8,92 & 9,88 & 9,72 & 12,59 & 13,76 \\
\hline
\end{tabular}

Як бачимо з табл. 6, для досліджуваних $€$ характерним досить високий креативний потенціал візуальної креативності. Крім того, наведені дані дозволяють говорити про онтогенетичний характер ії розвитку, про що свідчить збільшення оцінок від 8,92 балів в 10-річних підлітків до 13,76 балів в 14-річних. Зауважимо, що зростання візуальної оригінальності дещо уповільнюється в 12 років, оскільки її значення $є$ меншим за результати 11-річних підлітків.

Таблиця 7

Значущість відмінностей за показником візуальної оригінальності

\begin{tabular}{|c|c|c|c|c|}
\hline & \multicolumn{4}{|c|}{ Групи досліджуваних, що порівнюються } \\
\hline Вік & $10 / 11 \mathrm{p}$. & $11 / 12 \mathrm{p}$. & $12 / 13 \mathrm{p}$. & $13 / 14 \mathrm{p.}$ \\
\hline $\mathrm{p}$ & 0,593 & 0,928 & 0,027 & 0,022 \\
\hline $\begin{array}{c}\text { Підвищення } \\
\text { оцінок }\end{array}$ & незнач. & незнач. & знач. & знач. \\
\hline
\end{tabular}


Перевірка достовірності відмінностей оцінок досліджуваних в різних вікових групах за t-критерієм (табл.7) дозволила виявити статистичну значущу різницю між результатами підлітків $12 / 13$ років (р $=0,027)$ і $13 / 14$ років $(p=0,022)$. Натомість у підлітків $10 / 11$ і $11 / 12$ років ми спостерігаємо уповільнення здатності створювати оригінальні візуальні образи. Виходячи з цього, ми можемо говорити, що у 12-14 років відбуваються позитивні зрушення у розвитку процесів візуальної трансфрормації та оригінальності створюваних образів.

Для більш глибокого вивчення динаміки розвитку креативності в різні вікові періоди ми здійснили кореляційний аналіз взаємозв'язків між показниками методики П. Торренса. Важливими для аналізу міжструктурних зв'язків креативності в підлітковому віці можуть стати дані про кількість значущих кореляцій у кожному віковому періоді (табл.8).

Таблиця 8

Кількість значущих коефіцієнтів кореляції у кожному віковому періоді

\begin{tabular}{|c|c|c|c|c|}
\hline & Слабкий & Середній & Високий & Найвищий \\
\hline 10 років & 3 & 5 & 1 & 1 \\
\hline 11 років & 1 & 3 & 6 & 1 \\
\hline 12 років & 1 & 7 & 1 & 1 \\
\hline 13 років & 1 & 6 & 1 & 2 \\
\hline 14 років & 1 & 1 & 7 & \\
\hline
\end{tabular}

Проведений аналіз значущості кореляційних зв'язків між показниками $€$ підставою для висновку про зміцнення зв'язків між показниками креативності, а також свідчить, що починаючи з 11 років структура креативності стає більш цілісною, але необхідно зауважити, що 12-річний вік $є$ критичним у розвитку структури креативності. 
Детальний аналіз динаміки розвитку продуктивності показує, що він має неоднозначний характер. Виявлено якісне зростання показників візуальної продуктивності у віці 12/13 років, що свідчить про суттєвий ріст можливостей креативної сфрери підлітків, пов'язаних з активністю висування візуальних гіпотез. Уповільнення розвитку даної можливості зафріксовано у віці 11-12 років. Виявлено суттєве зниження продуктивності у віці 13/14 років, що дозволяє розглядати даний віковий період як критичний у розвитку активності висування візуальних гіпотез.

Зафріксовано найбільший діапазон індивідуальних оцінок за показником вербальної креативності 13-14-річних підлітків, що свідчить про розширення креативного потенціалу процесів семантизації візуальних вражень. Виявлено, що динаміка зростання результативності досліджуваних за даним показником вирізняється онтогенетичними закономірностями розвитку. Якісне зростання креативного потенціалу процесів вербалізації відбувається з 12 до 14 років, в той час як у віці 10-11 років відбувається уповільнення його розвитку. Провідною ознакою старшого підліткового віку (12-14 років) $є$ інтенсивний розвиток процесу вербалізації візуальних вражень та суттєве зростання оригінальності їх семантичної інтерпретації.

Виявлено найбільший діапазон варіативності індивідуальних оцінок з візуальної оригінальності у 10 та 13 років, що засвідчує зростання креативного потенціалу візуальної трансформації. Суттєве зростання оригінальності візуальних трансформацій $є$ характерним для старших підлітків від 12 до 14 років, може свідчити в певній мірі про початок становлення індивідуальних візуально-мисленнєвих стратегій в творчій діяльності [7].

Звернемося до аналізу змістових характеристик креативності, діагностика яких проводилася за допомогою методики „Зірки та хвилі” 
Урсули Аве-Лаллемант [1]. Досліджуваним давалася інструкція намалювати „Зоряне небо над хвилями”. Важливим елементом у малюнку $є$ те, чи зображує учень тільки зірки і хвилі, чи намагається надати малюнку вид цілісного зображення. Виконання методики не обмежується у часі, і вона надає свободу у вираженні індивідуального „бачення”, що $€$ однією 3 необхідних умов прояву креативних здібностей.

Для нас цікавим у методиці є показник візуальної оригінальності. Для цього ми використовували виділені автором методики, п'ять способів рішення тестового завдання, за допомогою яких можна визначити рівень візуальної креативності. Формальне рішення малюнок $є$ швидше декоративним, аніж змістовним, в ньому відсутні будь-які додаткові деталі. Предметне рішення характеризується реалістичністю зображення, у малюнку відсутнє естетичне осмислення поставленого завдання i прагнення зобразити щось прекрасне. Емоційне рішення вирізняється особливою емоційною атмосферою, яка найчастіше притаманна малюнкам зоряного неба і моря. Емоційне рішення найчастіше проявляється в малюнках, які мають образне вирішення. Образне рішення передбачає цілісне наочне зображення зірок над хвилями. Малюнки цього типу вирізняються тенденцією до обміркованої організації елементів простору, додаванням барвистих деталей, спостерігається бажання надати закінченого вигляду малюнку, у сюжеті якого кожна деталь має своє логічне призначення. Смислове рішення $є$ найвищим показником візуальної креативності, оскільки зображення характеризується смисловим змістом і прагненням передати певну ідею.

Потрібно відзначити, що способи рішення часто поєднуються між собою. Так смислове рішення може бути образно-смисловим або 
емоційно-образним; предметне рішення може сполучатися із формальним підходом у вирішенні завдання.

Проведене дослідження змістових характеристик креативності дозволяє зробити низку висновків щодо особливостей їх розвитку та зв'язку з процесуальними характеристиками.

Виходячи з аналізу результатів 10-річних підлітків, для них $є$ характерним прагнення осмислено підійти до поставленого завдання в міру своїх можливостей. Всі елементи об'єднуються у цілісну композицію і сповнені емоційною атмосферою за рахунок додавання яскравих елементів. Натомість в 11-12 років спостерігається зниження показника емоційно-забарвлених смислових рішень через різке збільшення предметно-фрормальних способів вирішення завдання, який характеризується надмірною реалістичністю і декоративністю елементів, позбавлених змістовного навантаження.

Аналіз показників процесуальних характеристик креативності показує, що саме в 11-12 років відбувається зниження продуктивності візуально-мисленнєвої сфрери, що проявляється у зменшенні активності висування візуальних гіпотез щодо невизначених стимулів і створенні на їх основі завершених зображень. У цей же віковий проміжок ми спостерігаємо уповільнення розвитку категоріальної гнучкості, що проявляється у збідненні процесів семантичної інтерпретації візуальних вражень на основі підключення словеснокатегоріального апарату. Також відбувається зниження рівня вербальної креативності, який у 11-12 років $€$ нижчим ніж в інших вікових групах і візуальної оригінальності, сягаючи найнижчого рівня саме у 12 років.

Зростання рівня активності висування візуальних гіпотез відбувається у 13 років. Водночас зростають показники вербальної і візуальної оригінальності. Що стосується змістових показників 
креативності, то саме у цьому віці ми спостерігаємо збільшення частки емоційно-образно-смислових рішень. Малюнки знову стають більш емоційними і осмисленими, а загальна композиція - продуманою, цілісною і завершеною.

Наступне зниження рівня продуктивності ми спостерігаємо в 14річних підлітків, що проявляється також і у змістових характеристиках креативності: знову зростає частка предметно-фрормальних рішень. Малюнки в основному спрямовані на виконання чітко поставленого завдання без привнесення оригінальних ідей. Середньоарифметичні значення категоріальної гнучкості в цьому віці $є$ більшими за показники 13-річних підлітків, але якщо звернутися до аналізу варіативності індивідуальних показників, то верхня межа 14-річних підлітків $є$ на рівні максимальних значень, які отримали підлітки 13 років. Аналогічні висновки можна зробити щодо вербальної і візуальної оригінальності, середньоарифметичні значення свідчать про їх зростання, але окремі досліджувані 13 років показують кращі результати порівняно із креативними підлітками 14 років.

Проаналізувавши результати отримані за допомогою методики „Зірки і хвилі”, ми можемо констатувати збільшення зображень сповнених смислу і емоційної атмосфрери, а їх композиція стає більш цілісною і завершеною. Малюнки набувають рис реалістичності і декоративності та смислового навантаження. Сприятливим для розвитку змістових характеристик візуальної креативності $€$ вік у 10 та 13 та 14 років.

Проведений одночасно аналіз розвитку процесуальних характеристик візуальної креативності показав, що одночасно 3 підвищення рівня розвитку її змістових характеристик підвищується рівень розвитку окремих ії̈ процесуальних характеристик, зокрема, це 
стосується активності висування візуальних гіпотез і візуальної оригінальності.

Одержані результати дозволяють зробити узагальнення про те, що розвиток змістових компонентів візуальної креативності відбувається паралельно із розвитком її процесуальних характеристик. Як змістові так і процесуальні компоненти мають у своєму розвитку як сприятливі періоди так і періоди спаду, які співпадають у часі.

Перспективним на нашу думку $є$ продовження дослідження у напрямку вивчення інших властивостей та функцій візуального мислення та їх розвитку.

\section{תimepamypa:}

1. Зинченко В. П. Живое знание / В. П. Зинченко. - Самара: Издво Самар. гос. пед. ун-та, 1998. - 4. 1. - 248 с.

2. Арнхейм Р. Новые очерки по психологии искусства: Пер. с нем. / Р. Арнхейм - М.: Прометей, 1994. - 352 c.

3. Беспалов Б. И. Действие: психологические механизмы визуального мышления / Б. И. Беспалов. - М.: Изд-во Моск. ун-та, 1984. - 320 с.

4. Симоненко С. М. Психологія візуального мислення: стратеаіально-семантичний підхід / С. М. Симоненко. - Одеса: ПНЦ АПН України, 2005. - 320 с.

5. Стратегії творчої діяльності: школа В. О. Моляко / За загальною редакцією В. О. Моляко. - К.: «Освіта України», 2008. - 702 с.

6. Симоненко С. М. Вікові особливості розвитку візуального мислення у підлітків / С. М. Симоненко // Наука і освіта. - 2001. - № 1. - C. $57-60$.

7. Аве-Лаллемант У. Графический тест «Звезды и волны» / У. АвеЛаллемант. - СПб.: Изд-во «Речь», «Семантика-С», 2002. - 240 с.

References: 
1. Zinchenko V. P. Zhivoe znanie / V. P. Zinchenko. - Samara: Izd-vo Samar. gos. ped. un-ta, 1998. - Ch. 1. - 248 s.

2. Arnkheym R. Novye ocherki po psikhologii iskusstva: Per. s nem. / R. Arnkheym - M.: Prometey, 1994. - 352 s.

3. Bespalov B. I. Deystvie: psikhologicheskie mekhanizmy vizualnogo myshleniya / B. I. Bespalov. - M.: Izd-vo Mosk. un-ta, 1984. - 320 s.

4. Symonenko S. M. Psykhologhija vizualjnogho myslennja: strateghialjnosemantychnyj pidkhid / S. M. Symonenko. - Odesa: PNC APN Ukrajiny, 2005. - $320 \mathrm{~s}$.

5. Strateghiji tvorchoji dijaljnosti: shkola V. O. Moljako / Za zaghaljnoju redakcijeju V. O. Moljako. - K.: «Osvita Ukrajiny», 2008. - 702 s.

6. Symonenko S. M. Vikovi osoblyvosti rozvytku vizualjnogho myslennja $u$ pidlitkiv / S. M. Symonenko // Nauka i osvita. - 2001. - № 1. - S. 57-60.

7. Ave-Lallemant U. Graficheskiy test «Zvezdy i volny» / U. Ave-Lallemant. - SPb.: Izd-vo «Rech», «Semantika-S», 2002. - 240 s. 